\title{
RELIGIOUS EDUCATION AND ADOLESCENT RELIGIOSITY (PART 1: URBAN AND RURAL MADRASAH ALIYAH CHARACTERISTICS IN LOMBOK ISLAND)
}

\author{
Mira Mareta \\ Universitas Islam Negeri Mataram, NTB, Indonesia \\ mira_mareta@uinmataram.ac.id
}

\begin{abstract}
The current social circumstances at the spiritual level have brought an enormous influence on the establishment of religious behavior in adolescent students, both in the level of belief, practice, and religious experience. Religious education in the madrasah environment has a strategic position in building students' religious behavior. This study aims to explain why the rural and urban madrasah environment context is essential to observe the role of religious education, especially Islamic education, in building students' religious behavior in Lombok island. Then it sorts out the madrasahs characteristics or uniqueness from the two different regions, rural and urban. This research is qualitative psychological research with ecological contextual theory as the theoretical framework. The data analysis method is descriptive and holistic by employing three flows of interacting activities, e.g., reducing data, presenting it, and drawing conclusions. Data was obtained through documentation, observation, and in-depth interviews. This research was conducted in six madrasahs, i.e., two Madrasah Aliyah located in the downtown, and four Madrasah Aliyah, which geographically represent the category of the rural madrasah. The research results indicate that the spiritual development of the students cannot be separated from the religious education context in their environment. In urban areas context, the madrasah environment has formal systemic characteristics, is supported by strong management and leadership, maintains the madrasah stability and conduciveness by implementing a power strategy through a set of rules and code of conduct. Meanwhile, madrasas in rural areas have flexible, dynamic, and adaptive characteristics, in which education takes into account cultural aspects and values applied in the community.
\end{abstract}

Keywords: religious education, religious behavior, youth religiosity, rural madrasah, urban madrasah.

\section{INTRODUCTION}

The religiosity phenomenon places humans in an actual level of wholeness between the spiritual and physical aspects, which are reflected in their religious behavior. Facts concerning human religious behavior indicate 
Mareta, M. (2021). RELIGIOUS EDUCATION AND ADOLESCENT RELIGIOSITY (PART 1: URBAN AND RURAL MADRASAH ALIYAH CHARACTERISTICS IN LOMBOK ISLAND). Jurnal Tatsqif, 19 (2), 192-215. https://doi.org/10.20414/itq.v19i2.4317

that religious education contributes essentially to building human religiosity. Langgulung (2003:31) states that a good education has contributed to individual growth, including physical growth in both structural and functional terms.

As mentioned in Daradjat (1978:174) research result, five psychological problems usually emerges in adolescents' character and religion, i.e.: 1) there is a difference between what they learn in school and what is found in society, 2) there is a difference between religious teachings and modern knowledge, 3) adolescent did not perform their religious teaching, especially to pray/șalāh, 4) experience anxiety because their belief in God is sometimes shaken, and 5) question whether love is against religion.

Discussions concerning religious education and adolescent religiosity have recently come up, among others, Nirwana's (2021) article describing the psychology education concept of Muslim adolescents' religiosity in their motivation to be religious. Siroj, Sunarti \& Krisnatuti (2019) explores the aspects of religious function within the family, dealing with threats, peer interaction, and adolescent religiosity. Winurini (2019) discusses the relationship between religiosity and mental health in Islamic boarding schools in Tabanan. Hadi (2017) discusses the Senior high school adolescent religiosity by analyzing the function and role of Islamic religious education in establishing students' personalities.

At least three main reasons are underlying this paper's urgency-first, the complexity of adolescent problems in rural and urban areas on Lombok Island. On Lombok island, adolescents are filled with typical problems, such as sexual urges, work, relationships with parents, social interactions, cultural interactions, emotions, personal growth, social problems, too much leisure time, finances, health, and religion. These changes in attitudes and behavior encourage the intention to be left alone, feel bored, incoordination, social antagonism, high tempered emotions, loss of self-confidence. Psychologists' most frequently expressed example is that late adolescence's measurement is 
Mareta, M. (2021). RELIGIOUS EDUCATION AND ADOLESCENT RELIGIOSITY (PART 1: URBAN AND RURAL MADRASAH ALIYAH CHARACTERISTICS IN LOMBOK ISLAND). Jurnal Tatsqif, 19 (2), 192-215. https://doi.org/10.20414/itq.v19i2.4317

not the same between adolescents in rural and urban areas. According to Daradjat (1978:38), the long phase of adolescence is not owned by simple people, and they may not even know that phase at all. In a traditional society, people only know children or adults. This thought also occurs to rural adolescents on the Lombok island, of which the rural boys almost have the same responsibilities as adults. Many young men are accustomed to earning their living to acknowledge their existence within society quickly. There is some kind of compulsion to enter the adult realm at a young age. Likewise, teenage daughters are also "suddenly became a wife/mother." As in the research results by Bennet (2016: 241), calling the adolescent with the term "teen mothers" or "school girl mothers" because they married in their teens, even married when they were students. This trend indicates that rural adolescents on Lombok Island have their characteristics compared to urban adolescents. This trend has also occurred in some madrasah aliyah in rural areas; their students' numbers are shrinking in the second or third year because they are married or invited to marry (Hartono, 2016).

The above fact is often found in rural students today, but there is another fact that students also make many adjustments and polish skills to survive in the information technology challenges, which no longer leaves a barrier even though it reaches the rural areas. This fact is the second reason for this study. The fact that the geographical and demographic location of the Lombok island causes complexity of problems for the community, including adolescents, one of which is due to the rapid tourism on the island, resulting in many areas becoming the center of tourist destinations and several madrasas located in rural areas is too close to these tourist destinations center, beaches, mountains, and traditional village tour.

The complexity is generally found in urban areas, but it does not apply to Lombok Island because the rural areas have their modernity challenges, although in different forms. Madrasas, which should be located in rural areas, are too close to tourist destinations so that madrasas are faced with the 
Mareta, M. (2021). RELIGIOUS EDUCATION AND ADOLESCENT RELIGIOSITY (PART 1: URBAN AND RURAL MADRASAH ALIYAH CHARACTERISTICS IN LOMBOK ISLAND). Jurnal Tatsqif, 19 (2), 192-215. https://doi.org/10.20414/itq.v19i2.4317

globalization threats and challenges that can threaten their identity, especially the students' religious integrity. Allegedly, there is some resistance in maintaining the traditions of indigenous peoples, causing a gap in religious beliefs and behavior in the community, including Madrasa Aliyah students. Umam (2006:2) underlines that at least three central issues trigger the complexity of the religious practice issues in rural areas on Lombok Island. First, modernization has existed. Second, the active penetration of Islamic da'wah does not subside because some assume that customs or traditions are not compatible with Islamic teachings, and thirdly, massive implications of government policies such as local transmigration to specific areas in rural areas. Modernity triggers social changes to Lombok people, including the penetration of government policies establishing several remote areas on Lombok island serve as the center of tourist destinations.

The two reasons above converge to the third reason: the penetration or intervention of Islamic da'wah is represented by establishing Islamic educational institutions (madrasas). As emphasized by Budiwanti (2000: 320), that the madrasah establishment in Bayan (for example) is as a center of da'wah activities for the Waktu Lima community (nota bene is a new settler) to make an invitation to the Wetu Telu community. Thus, the formation of adolescent religious behavior (in particular) cannot be separated from religious education conducted by madrasas, both in rural and urban areas. This study is not to compare rural and urban madrasas. However, the friction between modernity and tradition in the community, both in urban and rural areas, is a fact that cannot be denied and has affected behavioral changes that may take place evolutionarily or revolutionary.

The madrasas presence as the Islamic education institutions becomes the answer and hope because, in reality, the role of religious education in families and communities is alleged cannot provide answers to the challenges of modern life. Nonetheless, there is a phenomenon of attraction between the three elements of education between parents, teachers in madrasas, and the 
community in establishing adolescent religious behavior, which inevitably causes adolescent conflict.

Based on the above background, this paper aims to explain why the context of the rural and urban madrasah environment is essential in observing the role of religious education in building students' religious behavior on Lombok island. As for how (1) the internalization of the religious education values in rural and urban Madrasah Aliyah students on Lombok Island; (2) the implications of religious education on the religious behavior in rural and urban Madrasah Aliyah students on Lombok island, will be explained further in another article.

\section{THEORETICAL BASIS}

As the formulation of the problem, this research will identify and analyze how the students' role in religious education mold adolescent religious behavior in different regional settings. Many aspects are taken into account to observe how adolescent religious behavior behaves. Skinner's behaviorism advocates emphasize the observed behavior and environmental determinants. Furthermore, according to Skinner (1904-1999), development is the behavior itself. Development is the outcome of learning and often changes along with acquiring experience in the environment. Other behaviorists such as Bandura developed Skinner's notion with cognitive, social learning theory. Bandura stated that behavioral, environmental, and personal/cognitive factors could interact reciprocally, such as beliefs, planning, and thinking. In Bandura's view, the environment can influence a person's behavior, but many things to consider. The environment is vital for behavioral development, including religious behavior. In this study, the author uses Bronfenbrenner's ecological contextual theory approach, including the microsystem, mesosystem, exosystem, and macrosystem (Bronfenbrener, 1979; 1993: 39-40). 
First, the microsystem is the closest to the child's personality, including family, teachers, individuals, peers, schools, the environment, and children encounter every day. In this study, the setting is rural and urban madrasas. Second, the mesosystem is the interaction between the factors in the microsystem. In this study, the relationship between micro-systems is described in religious activities both developed in the classroom, internally, and externally. Third, Exo systems are social settings in which individuals do not have an active role, but the crucial decisions taken will impact people directly related to them. Alternatively, according to exosystems, it simply involves individuals experiences who do not have an active role in it, for instance, children on their relationship between the parents' home and workplace, or parents, their relationship between the school and the peer group environment, perhaps their friend parent's network, and local school board activities. Fourth, the macrosystem includes the culture in which individuals live. Cross-cultural studies - comparisons between one culture and the other cultures or more - provide information on development in general.

In the context of this study, the authors assume that religious behavior in adolescents should be studied and analyzed based on the environmental context where they live. Djohar (2000:117) once described children who live in rural areas surrounded by nature with their geographical situation and the school as the dominant component. As a result, the attractiveness formed strong school knowledge and creativity in utilizing and manipulating environmental conditions. In contrast to children living in urban areas full of science and technology, with varied pollution contamination, be it noise, waste, or population density, their developmental stage is more dominated by challenges causing discussion or speaking reactions, and their way of thinking is further comprehensive. According to him, children's knowledge and technology in urban areas are obtained from the school environment and the actual environment in their environment. In addition, they are faced with 
boredom that barriers their emotional maturity. Knowledge or global association also has been felt by children who live in urban areas. These circumstances encourage children in urban areas to have broader knowledge, and it is easier to understand lessons related to environmental conditions outside the school.

Therefore, it is natural that urban children have a broader perspective than children in rural areas. Then how does religious behavior is influenced by their environmental context? From the ecological contextual theory perspective, family, school, community, and peers must not be one-sided if one wants to get comprehensive research results. They are a unified system influencing student development (Germain \& Bloom, 1999:285).

\section{METHOD}

The setting in this study is that the researcher took two extreme points in taking sampling in madrasah to photograph two different poles. Urban madrasah is represented by State Madrasah Aliyah (MAN) 1 and MAN 2 Mataram, located in the downtown capital city of West Nusa Tenggara province. Meanwhile, rural madrasas are represented by four Madrasah Aliyah (MA) with specific categories. Researchers choose madrasas in rural areas that were classified as remote or underdeveloped villages with several categories, including; geographical aspects, accessibility of educational facilities, and the existence of Remote Indigenous Communities (KAT), precisely, MA located in mountainous and coastal areas with Indigenous Peoples Areas category: 1) MA Nurul Ijtihad Al Ma'arif NU Lenser, Kuta Village, Pujut District, Central Lombok Regency, (2) MA Nurul Mujahidin Selong Belanak, West Praya District, Central Lombok Regency, (3) MA Ma'arif Riyadul Falah Aikperapa, Aikmel District, East Lombok Regency and (4) MA Gaust Abdurrazak Nahdharul Wathan (NW) Tumpang Sari, Senaru Village, Bayan District, North Lombok Regency. For example, the Bayan District is a 
rural area where the Sasak village community lives, known as Wetu Telu followers

This research uses a qualitative research methodology. Qualitative research in the domain of psychology is a research methodology to understand the meaning of individual experiences based on the behavior causing it and the mental activity underlying it with a central phenomenon in the form of psychological constructs that are understood from the research subject's perspective (Herdiansyah, 2015: 61). This qualitative research is descriptive, phenomenological, documentary, and understanding (Bogdan \& Biklen, 1982:45-46).

The data collection method was carried out through documentation, observation, and in-depth interviews in this study. The data sources selection in the study was determined by purposive sampling by considering their compatibility with the research interests. The use of purposive is a step adapted to the research approach applied (qualitative) so that the matters sought to stand out and are easier to find their meaning (Muhadjir, 2000:149). The data analysis method in this study is descriptive and holistic, using three activity lines that interact continuously with each other, i.e., reducing data, presenting it, and drawing conclusions or verification (Miles \& Huberman, 1992: 17-19).

\section{DISCUSSION}

The establishment of madrasas in rural and urban areas has a different historical background. Madrasas in rural areas are educational institutions integrated and inseparable from their life and culture to be categorized as community-based education. Madrasas grow and develop in the middle of society's dynamics, MA Nurul Mujahidin and MA Nurul Ijtihadi, located on the coast of Kute Beach and Selong Belanak Beach (these beaches are local and foreign tourist destinations), has undergone many transformations from time 
to time. The position between madrasas, society, and culture influences each other, thus affecting the religious education system.

The presence of madrasas in rural areas certainly has a different history from the establishment of madrasas in urban areas-for instance, the establishment in the Bayan area. Although the Bayan community seems to disagree with the school establishment, over time, the madrasas can open two classes for each grade with 40 people each. However, this condition changed after the Bayan established SMA and SMK in 2012, specifically for MA Gauts Abdurrazak NW now only has one class each with 20 students (Ulumuddin, 2016). In contrast to MA Nurul Bayan, their students have kept growing in numbers until now.

There are only 2 (two) Madrasas Aliyah in the Bayan sub-district itself, both of which apply to the boarding system (stay in dormitories), but in MA Ghauts Abdurrazak, most students choose to go to school from their homes.

Another madrasas characteristic in rural areas is that they are educational institutions built on or based on trust and community participation because the existence of madrasas is supported and driven by the Tuan Guru (Kyai). In Lombok, Tuan Guru not only acts as a role model in religious life (religious leader) but also as an educational figure (chairman of the foundation) or madrasah holder (madrasah headmaster).

Referring to the research conducted by Junaedi on Madrasas in the Java Coastal areas, discussing study case in Wedung District, Demak Regency, it is revealed that there are four characteristics of madrasas in Java coastal areas; 1) the ideological identity, which is based on the ideology of ahl al-sunnah wa al-jama'ah, 2) the social capital identity, based on public trust and participation, 3 ) the populace identity is populist education, education for all, 4) the Kyai based identity, the existence of these madrasas are driven by the kyai (Junaedi, 2013:379-340). 


\section{Educational infrastructure and supporting facilities}

Madrasas should have complete facilities and infrastructure. However, rural madrasah has many drawbacks in terms of facilities. By viewing from the aspect of facilities and infrastructure, all rural madrasas have in common that the land of which the madrasah is located is shared with the educational institutions under it, such as Raudhatul Athfal (RA), Madrasah Ibtidaiyyah (MI), and Madrasah Tsanawiyyah (MTs). Thus, it can be deduced that they share the playground, the same atmosphere, and the direct or indirect interaction between students at all grade levels.

Institutionally, madrasas can be seen from the history of their establishment, how students and educators are, and its infrastructure. Analyzing the history in establishing urban madrasas has differences with rural madrasas, if rural madrasas grow and develop based on the initiative of the community leaders, especially the local ulama, who care and bring the idea of education renewal. Populist rural madrasas (borrowing Steenbrink's term) that come from the communities are intended for the surrounding community and respond to its people's requirements. Seeing from the building, what is striking is that in rural madrasas, commonly, the Tuan Guru's house (the head of the foundation) is in the madrasahneighborhood. According to Ziemek (1986: 105) that most rural madrasas between Tuan Guru's house (chairman of the foundation), mosques, dormitories, and madrasas are one unity. Students and their teachers can meet any time, even though they do not live in the dormitory, but they are residents around the madrasa.

Meanwhile, urban madrasas were established as urban or municipal phenomena. The initiatives come from the authorities (government), practically madrasas have no difficulty absorbing all modern elements and facilities, such as permanent buildings, well-organized curriculum, and relatively steady budget funds because the government directly disburses it. 
Mareta, M. (2021). RELIGIOUS EDUCATION AND ADOLESCENT RELIGIOSITY (PART 1: URBAN AND RURAL MADRASAH ALIYAH CHARACTERISTICS IN LOMBOK ISLAND). Jurnal Tatsqif, 19 (2), 192-215. https://doi.org/10.20414/itq.v19i2.4317

\section{Teaching Staff and education staff}

Teaching staff, often called teachers, are one of the primary keys to improving madrasah's quality. According to Rosyada (2017: 29), there are four essential skills for the teachers as a minimum standard quality, first is professional skills. Second, teachers ought to have adequate teaching skills. The third is to have good personal intelligence. Furthermore, fourth is having good social intelligence. Likewise, the ideal madrasah must have academic staff who can highly contribute to the success and organizing qualified education. Educational personnel must be able to preserve madrasa's good name, profession, and position conforming to the trust given to them, carry out educational tasks for which they are responsible, strive to improve professional abilities including intellectual abilities, integrity, and social personality, both in the working and public environment.

In urban areas, MAN 1 Mataram has 59 (fifty-nine) teaching staff (including the headmaster and deputy headmaster) who have taken technical coaching on the implementation of K-13, and 41 (forty-one) people have been certified. Meanwhile, MAN 2 Mataram has 61 (sixty-one) educators, including the principal and vice-principal of the madrasah who have taken technical coaching on the $\mathrm{K}-13$, and 42 (forty-two) implementation as certified educators. As for the quantity of educational personnel has met the standard, and some are working on the administration division, library staff, and the madrasah operator (EMIS) section.

Meanwhile, none of the teaching staff in rural madrasas hold Civil Servants status (there were no PNS teachers assigned in the 4 sample madrasas). In addition, teaching staff in rural madrasas are also education personnel. For example, some serve as administrative staff or as EMIS (madrasah data collection) operators. There are nine male and two female teachers at MA Nurul Ijtihad NU Lenser (11 people), one of whom is the headmaster, and three people have received certification. As for education staff, madrasas empower the school alumni as non-permanent employees, 
and teachers are usually involved in administrative matters (Observation, 7 January 2016).

Likewise, MA Nurul Mujahidin Selong Belanak has 12 teachers (including one headmaster and one deputy headmaster) who are also certified. The education personnel is also a teacher or one who is assigned to help madrasas with administrative matters (Observation, 10 January 2016). Then MA Ghauts Abdurrazak NW has 15 male teachers and five female teachers, of which 2 have teaching certifications (Observation, 9 May 2017). Finally, MA Ma'arif Riyadul Falah Aikperapa has 17 educators (including one headmaster and two deputy headteachers) and two education staff (Observation, 14 December 2016).

Teaching staff, both in urban and rural madrasas, have the same responsibility in providing the best service for students in the learning process. Before carrying out teaching tasks, the teacher prepares to teach administration such as annual programs, semester programs, lesson units, and lesson plans, including preparing practice questions, mid-semester exam questions, semester final exam questions, teacher journals, and preparing learning media. Although it has not been entirely perfect yet in preparing learning tools, teachers have tried to fulfill the learning components they must prepare. Besides being administrative staff in the learning process, Islamic Religious Education teachers prepare to learn models and media adapted to the available learning tools and resources.

\section{The objective in education; madrasah vision and mission}

Every educational institution has its educational objectives; education is a systemic and planned activity as an organization. Thus, education is required to have clear objectives to be achieved. As for the educational purpose, according to Sheikh Muhammad al Naquib al Attas, there are two theoretical views, each with its level of diversity. The first theoretical view is that the educational purpose must be communal-oriented, i.e., the view that considers education as the primary medium to create good people for 
Mareta, M. (2021). RELIGIOUS EDUCATION AND ADOLESCENT RELIGIOSITY (PART 1: URBAN AND RURAL MADRASAH ALIYAH CHARACTERISTICS IN LOMBOK ISLAND). Jurnal Tatsqif, 19 (2), 192-215. https://doi.org/10.20414/jtq.v19i2.4317

democratic, oligarchic, and monarchical government systems. The second view is more individual-oriented, which focuses more on the students' needs, capacity, and interests (Daud, 2003:163).

As al-Taoumy al-Syaibani's (1979:339) opinion, divides the goals of education into three aspects, e,g: individual, social, and professional goals. With such comprehensive goals of Islamic education, the fundamental objective of Islamic education is to build to human beings who are devoted to Allah SWT. as the Creator. According to Langgulung (2003), as Nata (2001: 49) quoted, talking about the purpose of education cannot be separated from talking about human nature and the purpose of life. In other words, when we want to determine the direction and goals of education, we will talk about humans and the purpose of life because, essentially, the purpose of education is to maintain human life.

In achieving these educational goals, each madrasah has a vision and mission as the basis for providing education to achieve these goals. MAN 1 Mataram and MAN 2 Mataram, apart from having strong historical ties, in the curriculum and learning models of religious education almost have the same characteristics. MAN 1 and 2 Mataram set their missions with the intention to build an understanding and practice of the values of the religious teachings. So that these values animate all the educational processes described in subsequent missions, both understand that religious education is essential in achieving the educational purpose. Thus, the values of religious teaching are expected to align students' personalities in mastering science and technology. At the same time, rural madrasas' vision and mission in achieving educational goals are influenced by their affiliation with religious organizations above them. Only MA Nurul Mujahidin, who is not affiliated with any religious organization, wanted to achieve educational goals by any madrasa.

Rural and urban madrasah have the same goals based on national education objectives. It can be concluded that the three points becoming the core of both in translating educational goals are as follows: 1) Increasing 
students' knowledge to continue their education at a higher level; 2) Increase students' knowledge to develop themselves aligning to the science, technology and art development inspired by Islamic teachings; 3) Improve the students' ability as members of the community in holding reciprocal relationships with the social, cultural and natural environment inspired by Islam teachings. The efforts to materialize the educational objectives can be seen in how each madrasa's internalization of religious education values is carried out.

\section{Student admission, opportunities, and challenges}

In different places, different problems are faced in terms of madrasah location if, in urban madrasas, student input is easier to obtain, while in rural madrasahs, one must strive to get it. For observing the minimal number of madrasahs students in rural areas, it cannot be separated from various problems, both directly and indirectly, among others caused by several factors: (1) more interested in entering vocational schools, (2) colliding with the Merariq tradition, (3) Working to help parents. lebih tertarik masuk sekolah vokasional, (2) Terbentur tradisi merariq, (3) Bekerja membantu orang tua (Haq \& Hamdi, 2016; Bukhori, 8 March 2017; Salman, 17 May 2017).

The admission for prospective urban madrasah students is strictly selected. There are academic tests, Quran tests, recitation tests, and interviews. While rural madrasas do not conduct admission selection tests, anyone with a Junior High (SMP) diploma and categorized as a student can be accepted as a student (inclusive). The conditions faced by rural madrasas make the teachers have a central role in recognizing students throughout the education process. The emotional closeness between students and teachers is closer in rural areas than in urban areas because the students' quantity is very minimal. Likewise, the teacher's closeness to students' parents is because the student is regularly a member of the community around the 
madrasa. Emotional closeness is also proven that the principal or the head of the foundation lives close to the madrasah and also close to the community.

In fact, to create qualified madrasah graduates, the management of madrasa's students must be considered, starting from the selection of prospective students, preparation for learning, the learning process, coaching, and development, mentoring, providing broad opportunities for studying and evaluating learning outcomes corresponding to the principles of evaluation (Rosyada, 2017:27). Learning outcomes and achievements in madrasas are expected to benefit students, such as continuing their studies to the desired institution, entering the business sector or employment, working for other people, or opening up employment opportunities conforming to their competencies.

\section{Parents' purpose and expectations in religious education}

Fundamentally, objectives and expectations cannot be separated, and parents express them from general expectations to practical ones. At least three domains must be achieved to reach the objective or expectations, e.g., the cognitive (science), affective (moral), and psychomotor (deeds) domains. Assegaf added the domain of faith as the core of Islamic education (Assegaf, 2005: 187-188).

The following is a mapping of the parents' objectives and expectations that any parents in rural and urban students want to achieve. These are the four domains:

Table 1. Parents Objective and Expectation in Religious Education on Four Domain

\begin{tabular}{cl}
\hline Domain & \multicolumn{1}{c}{ Parents Objective and Expectation } \\
\hline Science & - Wants their children to study religion \\
& - Knowing the history and nature of Islam \\
& - Studying religious knowledge and understanding other general \\
& sciences \\
moral & - Understand the Sharia law in Islam \\
& - Be a pious child, have good character \\
& - Being exemplary for their younger siblings. \\
& - Grow up well, independent, and polite \\
& - Have limitations in associating according to religious teachings \\
\hline
\end{tabular}


Mareta, M. (2021). RELIGIOUS EDUCATION AND ADOLESCENT RELIGIOSITY (PART 1: URBAN AND RURAL MADRASAH ALIYAH CHARACTERISTICS IN LOMBOK ISLAND). Jurnal Tatsqif, 19 (2), 192-215. https://doi.org/10.20414/jtq.v19i2.4317

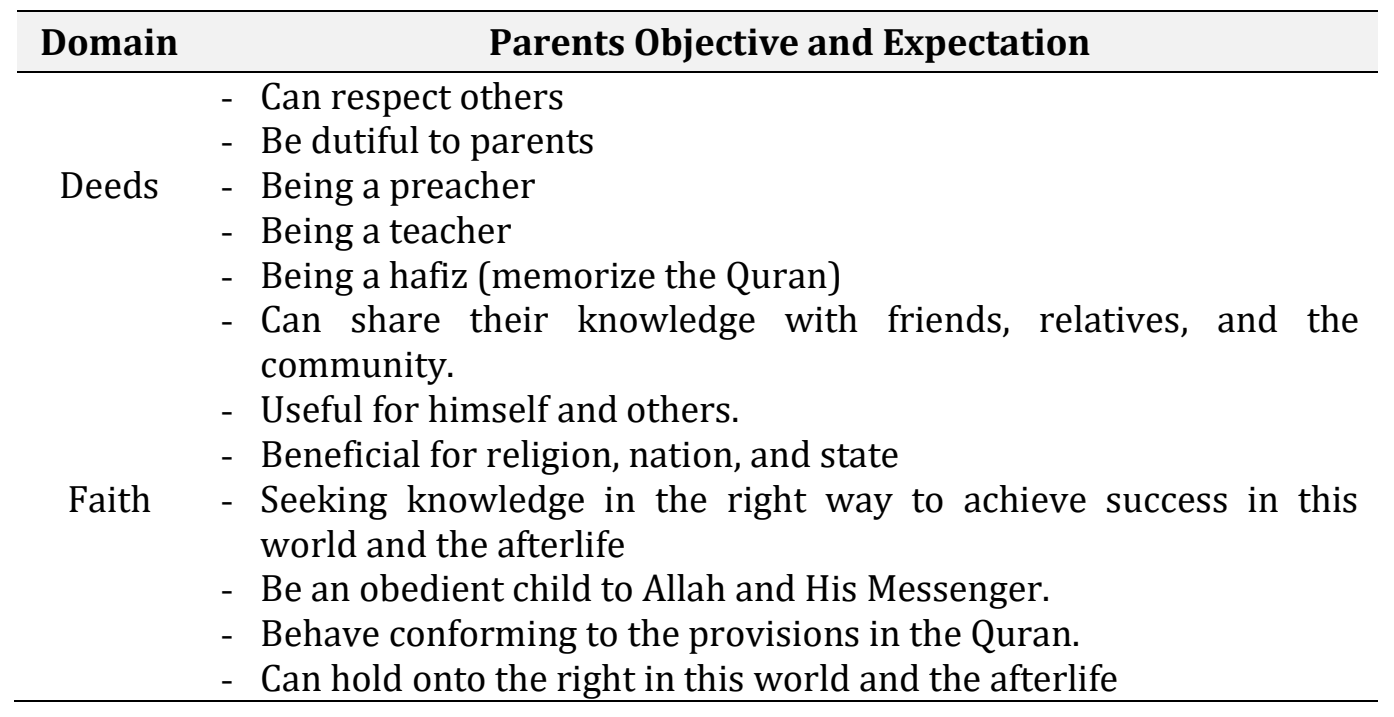

The four domains, of course, are very compatible with the educational objectives achieved by madrasas both in rural and urban areas. The parents' objectives and expectations in religious education meet the elements of knowledge, affection, psychomotor, and even faith domain. If it is deduced, parents want their children to have religious knowledge to build a personality compatible with religious teachings and have life skills, be it as a teacher, hafiz, preacher, especially can be helpful for religion nation and state.

Social experts describe the changes patterns or characteristics in society that will develop today and in the future, including first, modernization occurs in various aspects of life due to science and technological advances, resulting in changes of values, in which efficiency and productivity considerations get increasing.

Second, people's behaviors tend to be more functional. The relationship is only viewed from this society's religious and interested' perspective. A person's existence is primarily determined by how far he is functional for others. It is because a person's ability is increasingly needed individually. Strictly speaking, there is a shift in social relationships from practical to effective neutral in a society like this, as a change from personal and emotional relationships to distant and not personal relationships. 
The third is the public's need for information. In this society, a person's existence is primarily determined by how much and to what extent he can master information. Furthermore, fourth, people are live in an increasingly systematic and open society. Society is increasingly running and governed by an open system (Al Munawar, n.d.: 47-48).

According to the characteristics of these societal changes, education has shifted to educational institutions that can develop their quality corresponding to social development, i.e., education that can provide technological, functional, individual, informative, and open capabilities. However, amid this trend, people are actually very concerned about weakening abilities related to ethics and morals or virtue.

Moral education is relevant to religious education because what is good has a useful barometer from a religious perspective and vice versa. What is considered bad has a bad barometer from a religious perspective. In Islamic education, moral education is an important matter that must be instilled in students considering the current generation has been immersed in moral decadence. Here, it also lies in the central role of the family to establish interactive communication with children regarding their problems.

Rural and urban madrasas have conducted reorientation in developing Islamic education. According to education expert Christopher J. Lucas, education is a storehouse of extraordinary power, having access to all aspects of life, providing valuable information about how to live in the future, and helping future generations. In preparing its essential needs in facing changes, Islamic education is directed to providing the most expansive possible space for the essential functions of education, through the development of education with three policies;

a. Taking madrasas as a vehicle for building or practicing Islamic life;

b. Madrasas further clarify and strengthen the existence of Islamic educational institutions as community development to establish an 
intelligent, knowledgeable, productive generation conforming to the madrasah system.

c. Madrasas should be able to make Islamic educational institutions capable of responding to future demands. For this reason, madrasas are directed to produce human resources prepared to face the globalization era.

The above matters have been read carefully by both urban and rural madrasas, and the education component supports the role of religious education just fine. From the research results, the education component in rural and urban areas becomes strong support for religious education's role. In the ecological contextual theory perspective, the education component becomes a subsystem in all areas, be it micro-systems, meso-exo systems, and macro-systems, which are part of the environment press that directly and indirectly affect students' religious behavior.

From the ecological contextual theory perspective, human development is influenced by its environment. So students' spiritual development cannot be separated from the religious education context in their environment. If religious activities are considered a power in the madrasah environment and affect students' behavior in the system, this power will be called an environmental press that determines the direction of students' spiritual development. As stated by Garbarino and Abramowitz, that the environmental press is molded from suppressing circumstances and covering individuals that emerge psychological momentum, as in reactions, and tend to direct the individual in a specific direction (Andayani, 2004:47). Of course, specific pressures or conditions are directly related to students, and some are not. A reciprocal relationship between the individual and the environment will mold the students' behavior or attitude. Therefore, it is essential to see the diversity of students' development in terms of the madrasah context or educational institution supervising them. With the considerations above, it can be mapped according to the ecological contextual theory (as shown in 
Figure 1) that madrasas as an educational system contribute to students' religious behavior formation by analyzing three central systems.

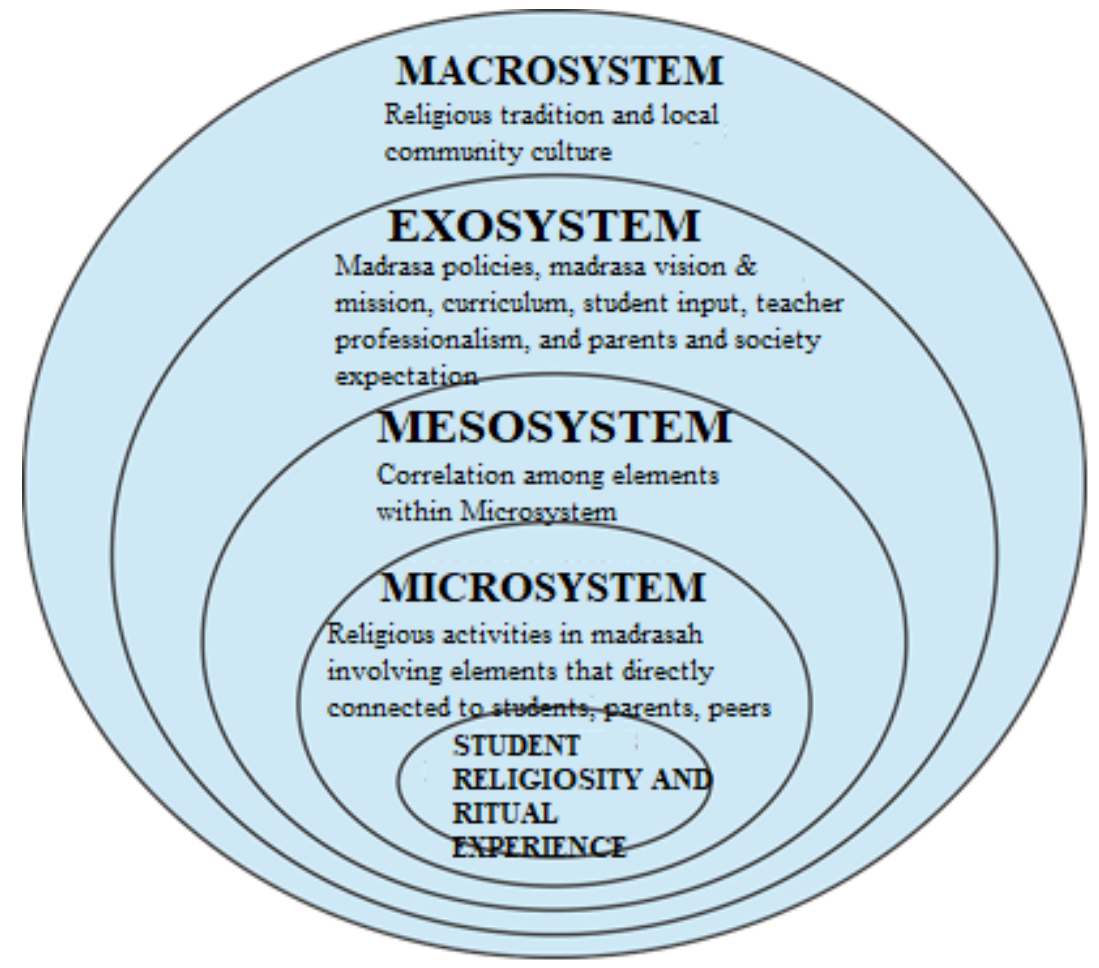

Figure 1. Students' Religious Rituals and Experiences of Ecological Contextual Theory Perspective

First, the microsystem and the mesosystem are environmental conditions directly related to students, that is, religious activities to internalize religious teachings values in the madrasah environment involving elements directly involved with students, such as parents/families, teachers, and peers. In this subsystem, interactions and relationships occur between elements inside the micro-system environment, called the mesosystem area, such as religious experiences interaction in the family with religious experiences in madrasas, religious experiences in madrasas with peers' religious experiences.

Second, the exosystem is a more extensive system in which students are not directly involved but so much influenced students' religious behavior, i.e., 
madrasah policies, parental expectations, student input, student facilities, and teacher professionalism. The outermost part of the student environment is the third macrosystem. In religious education, the religious traditions developed in the community become the pieces influencing students' religious behavior. Because according to Berk in Mujahidah, the culture referred to in this subsystem is behavioral patterns, beliefs, and attitudes. All products from a group of people are passed down from generation to generation (Mujahidah, 2015:173).

\section{CONCLUSION}

The student's religious development cannot be separated from the religious education context in their environment. Therefore, it is essential to see the development of students' diversity in terms of the madrasah or educational institution context overseeing them.

The madrasah environment in urban areas has formal systemic characteristics, is supported by strong management and leadership, and maintains its stability and conduciveness by implementing a power strategy through the madrasah rules and code of conduct. It is expected that the achievement of educational objectives based on the predetermined vision and mission can go without disruption, building students' character with good morals with a disciplined pattern by applying reward and punishment, habituation, and exemplary. Meanwhile, madrasas in rural areas have flexible, dynamic, and adaptive characteristics, in which education considers culture and values aspects applied in the community. So that in rural madrasas, a more persuasive approach is carried out, even though the path seems slow in reaching the predetermined vision, mission, and educational objective. However, Tuan Guru or Ustadz, who are very persuasive, becomes a specific trigger for madrasah sustainability. 


\section{BIBLIOGRAPHY}

Abdul. (2016). orang tua siswa MA Nurul Ijtihad Al Ma'arif NU Lenser. Interview. 10 Januari 2016.

Aflah, W. (2004). "Sasak di Persimpangan Posmodernism (Persimpangan Menuju Budaya Massa dan Budaya Populer)“ in Garis Tepi Masyarakat NTB Membongkar Nalar Sosial, Budaya dan Pembangunan di NTB. Yogyakarta: InSKRIP.

Al Munawar, S. A. (n.d.). Aktualisasi Nilai-Nilai Qur'ani Dalam Sistem Pendidikan Islam. Jakarta: Ciputat Press.

al-Toumy al-Syaibany, O. M. (1979). Falsafah pendidikan Islam, translated by H. Langgulung. Jakarta: Bulan Bintang.

Andayani, B. (2004). "Tinjauan Pendekatan Ekologi Tentang Perilaku Pengasuhan Orang Tua”. Buletin Psikologi 12, no. 1, Juni.

Assegaf, A. R. (2005). Studi Islam Kontekstual: Elaborasi Paradigma Baru Muslim Kaffah. Yogyakarta: Gama Media.

Bennet, L. R. (20016). Young Sasak Mothers-"Tidak Manja Lagi": Transitioning from Single, Daughter to Young Married Mother in Lombok, Eastern Indonesia, Dalam Youth Identities and Social Transformations in Modern Indonesia. Edited by K. Robinson. Leiden: Boston: Brill.

Bogdan, R. C. and Biklen, S. K. (1982). Qualitative Research for Education: An Introduction to Theory and Methods. Boston: Allyn and Bacon, Inc.

Brofenbrenner, U. (1993). "Ecological Models of Human Development," In International Encyclopedia of Education 3, 2nd. Oxford: Elsevier. Reprinted in Gauvain, M. and Cole, M. (Eds.). Reading on The Development of Children. New York; Freeman.

Bukhori. (2017). Pembina Pondok MA Ghauts Abdurrazak NW Tumpang Sari. Interview. 8 Maret 2017.

Daradjat, Z. (1978). Problema Remaja di Indonesia. Jakarta: Bulan Bintang. 
Djohar. (2000). Praksis Pendidikan Berwawasan Ekologi, dalam Menggagas Paradigma Baru Pendidikan, Demokratisasi, Otonomi, Civil Society, Globalisasi, edited by Sindhunata. Yogyakarta: Kanisius.

Germain. C. B. and Bloom, M. (1999). Human Behavior in The Social Environment AnEcological View. New York: Columbia University Press.

Hadi, M. (2017). "Religiusitas Remaja SMA (Analisis Terhadap Fungsi dan Peran Pendidikan Agama Islam dalam Membentuk Kepribadian Siswa)" Tapis: Jurnal Penelitian Ilmiah 1, No. 2, p. 304-322. https://doi.org/10.32332/tapis.v1i02.925.

Haq, H. Sy., and Hamdi. (2016). "Perkawinan Adat Merariq dan Tradisi Selabar di Masyarakat Suku Sasak", Perspektif 21, No. 3.

Hartono, E. (2016). Kepala MA Nurul Ijtihad Al Ma'arif NU Lenser. Interview. 10 Januri 2016.

Herdiansyah, H. (2015). Metodologi Penelitian Kualitatif untuk Ilmu Psikologi. Jakarta: Salemba Humanika.

http://kawasan.bappenas.go.id/index.php?option=com content\&view=categor y\&id=35:sub-direktorat-daerah-tertinggal\&layout=blog\&Itemid=65, dated 21 October 2014.

http://peristiwa.kampung-media.com/2017/12/06/praja-kalender-tahunanmaulid-dasan-agung-21931.

https://bisnis.tempo.co/read/1037110/ini-sebab-gerai-matahari-di-

lombok-city-center-ditutup/full\&view=ok, downloaded on 13 August 2019.

https://firstlomboktour.com/dokumentasi/masjid-islamic-center-lombok, diunduh pada tanggal 13 Agustus 2019.

Junaedi, M. (2013). “Madrasah di Pesisir Jawa Kasus Madrasah di Kecamatan

Wedung Kabupaten Demak", Disertasi. Postfraduate Program of UIN Sunan Kalijaga.

Langgulung, H. (2003). Asas-Asas Pendidikan. Jakarta: Radar Jaya Opset. 
Malik, A. (2015). Ketua Yayasan MA Nurul Bayan. Interview. 30 December 2015.

Miles, M. B. and Huberman, A. M. (1992). Analisis Data Kualitatif, translated by Tj. R. Rohidi. Jakarta: UI Press.

Muhadjir, N. (2000). Metodologi Penelitian Kualitatif, Edisi 4. Yogyakarta: Rake Sarasin.

Mujahidah. (2015). "Implementasi Teori Ekologi Bronfenbrenner dalam Membangun Pendidikan Karakter Yang Berkualitas, Lentera 19, no. 2, December.

Nata, A. (2001). Paradigma Pendidikan Islam, Kapita Selekta Pendidikan Islam. Jakarta: Grasindo.

Nirwana, A. (2021). Konsep Pendidikan Psikologi Religiusitas Remaja Muslim Dalam Motivasi Beragama. At-ta'dib: Jurnal Ilmiah Prodi Pendidikan Agama Islam 12, no. 1, p. $11-88$. https://doi.org/10.47498/tadib.v12i01.324.

Nurhayati, E. (2011). Psikologi Pendidikan Inovatif. Yogyakarta: Pustaka Pelajar.

Nyakranom, R. (2019), Penyuluh Agama Islam Kantor Urusan Agama Kecamatan Bayan. Interview. 27 May 2019.

Rachman, A. M. A. (1986). "Mencari Bentuk Sekola Kejuruan yang Cocok di Taraf Desa", in Sajogyo and P. Sajogyo, Sosiologi Pedesaan Jilid 2. Yogyakarta: Gajah Mada University Press, 1986.

Rosenau, Pauline M. (1992). Postmodernism and Social Sciences: Insights, Inroads, and Intrusion. Princeton: Princeton University Press.

Rosyada, D. (2017). Madrasah dan Profesionalisme Guru, Dalam Arus Dinamika Pendidikan Islam di Era Otonomi Daerah. Depok: Kencana.

Salman. (2017). Ketua Yayasan MA Nurul Mujahidin. Interview. 17 May 2017. Second world conference on Muslim Education, under the auspices of King Abdulaziz University \& Quaid-i-Azam University, 15 to 20 March 1980, Islamabad. 
Siroj, E. Y., Sunarti, E., \& Krisnatuti, D. (2019). Keberfungsian Agama di Keluarga, Ancaman, Interaksi Teman Sebaya, dan Religiusitas Remaja. Jurnal Ilmu Keluarga \& Konsumen 12, No. 1, p. 13-25. https://doi.org/10.24156/jikk.2019.12.1.13

Sudirman and Bahri. (2014). Studi Sejarah dan Budaya Lombok. NTB: Pusat Studi dan Kajian Budaya Provinsi Nusa Tenggara Barat, 2014.

Ulumuddin, A. (2016). Ketua Yayasan Madrasah Aliyah Gauts Abdurrazak Nahdhatul Wathan. Interview. 22 January 2016.

Umam, F., dkk. (2006). Membangun Resistensi, Merawat Tradisi: Modal Sosial Komunitas Wetu Telu. Mataram: Lembaga Kajian Islam dan Masyarakat IAIN Mataram.

Wan Mohd Nor Wan Daud. (2003). Filsafat dan Praktik Pendidikan Islam Syed M. Naquib al-Attas. Bandung: Mizan.

Winurini, S. (2019). "Hubungan Religiositas dan Kesehatan Mental pada Remaja Pesantren di Tabanan", Aspirasi: Jurnal Masalah-Masalah Sosial 10, No. 2, p. 139-15. https://doi.org/10.22212/aspirasi.v10i2.1428.

Zaenuri. (2018). Wakil Kepala MAN 1 Mataram. Interview. 19 February 2018. Ziemek, M. (1986). Pesantren Dalam Perubahan Sosial. Jakarta: Perhimpunan Pengembangan Pesantren dan Masyarakat P3M.

Zuhdi, M. H. (2016). Parokialitas Wetu Telu, Wajah Sosial Dialektika Agama Lokal di Lombok. Mataram: Sanabil. 